\title{
Dynamics of a Phaeocystis-dominated spring bloom in Belgian coastal waters. I. Phytoplanktonic activities and related parameters
}

\author{
C. Lancelot \& S. Mathot \\ Groupe de Microbiologie des Milieux Aquatiques, Université Libre de Bruxelles, avenue F. D. Roosevelt 50, B-1050 Brussels, \\ Belgium
}

\begin{abstract}
Phytoplanktonic activities were measured weekly during spring 1984 in Belgian coastal waters almost entirely dominated by Phaeocystis pouchetii colonies. Accurate methods were developed to measure photosynthesis and growth rates by colonial $P$. pouchetii cells, mucus secretion and excretion from colonies. Photosynthetic properties, although quite different for cellular photosynthesis and mucus secretion, were found to be independent of changes in environmental conditions. Maximal photosynthetic rates were respectively 0.09 and $0.16 \mathrm{~h}^{-1}$ for cells and mucus. Cellular specific growth rate, on the other hand, was inversely correlated to the level of ambient inorganic nitrogen. Extreme values for cell turnover rates were 0.12 and $0.38 \mathrm{~d}^{-1}$. A budget of metabolic activities of $P$. pouchetii colonies was established for the period of their bloom. The colonies photo-assimilated $94 \mathrm{~g}$ $\mathrm{C} \mathrm{m}^{-2} \mathrm{mo}^{-1}$. From this, a maximum of $84 \mathrm{~g} \mathrm{C} \mathrm{m}^{-2} \mathrm{mo}^{-1}$ was devoted to colonial biomass production and $7.5 \mathrm{~g} \mathrm{C} \mathrm{m}^{-2} \mathrm{mo}^{-1}$ was excreted from the colonies.
\end{abstract}

\section{INTRODUCTION}

It is now well established that inorganic carbon assimilated by phytoplankton during the photosynthetic process is not entirely devoted to biomass production, i.e. what is commonly called net primary production or growth. Rather, some photosynthetic products are excreted from the cells, mainly in the form of small molecules directly utilizable by planktonic bacteria (see review by Lancelot \& Billen 1986). Also some photosynthetic products are catabolized and provide energy and carbon skeletons for the synthesis of cellular material which can then proceed during the night as well as during the day (Cook 1966, Foy \& Smith 1980, Cuhel et al. 1984, Lancelot \& Mathot 1985a, Lancelot et al. 1986). These energy storage substrates occur mainly as reserve polysaccharides (Cook 1966, Foy \& Smith 1980, Lancelot \& Mathot 1985a). However, in the particular case of colonial algae such as Phaeocystis pouchetii, this physiological function is performed by the mucilaginous compounds which compose the colonial matrix (Lancelot \& Mathot 1985b). Protein synthesis, combined with an accurate cellular $\mathrm{C} / \mathrm{N}$ ratio, would therefore be recommended as a better index of phytoplankton growth than photosynthetic C assimilation.

For this reason, Lancelot et al. (1986) established a simple mathematical model to estimate Phaeocystis pouchetii cell growth in the water column. It is based on double control, by ambient inorganic nitrogen and light, of the light and dark protein synthesis rates.

Complementary to this model, we present in this paper data on measurements of photosynthesis rate by Phaeocystis pouchetii colonies. We show that these estimates, combined with those of $P$. pouchetii cell growth (Lancelot et al. 1986), give a maximal value for $P$. pouchetii colony growth in the water column. However, because of the particular mucilaginous structure of colonies, common methods for measurement of phytoplankton biomass and photosynthesis were not suit- 
able. The filtration procedure universally used for isolation of phytoplankton cells disrupts the colonies and solubilizes the mucus into seawater. At the present time, no gentle mechanical procedure exists for specific isolation of intact mucilaginous colonies. Filtrations on membranes of specific porosity combined with classical biochemical procedures (Lancelot 1983, Lancelot \& Mathot 1985a, Lancelot et al. 1986) were therefore recently developed during time-course studies of ${ }^{14} \mathrm{C}$ incorporation. This methodology allows distinction between photosynthesis rate and growth of cells, and also allows estimates of mucus secretion and of extracellular release of organic molecules from the colonies together with the latter's utilization by bacteria.

This paper reports results of such measurements conducted weekly during spring 1984 in Belgian coastal waters where spectacularly high biomasses of Phaeocystis pouchetii colonies follow a moderate bloom of diatoms. In addition to the establishment of the photosynthetic properties of these 2 phytoplanktonic communities, parallel measurements of seawater temperature, incident available light intensity and major nutrients were made in order to determine the environmental factors associated with the onset of the $P$. pouchetii bloom and the control of its main metabolic activities. From these, specific mathematical sub-models are used to estimate the growth of colonies in the water column. Finally we present a tentative budget of phytoplankton activities for the whole period of the $P$. pouchetii bloom.

\section{MATERIAL AND METHODS}

Sample collection. Experiments were performed in Belgian coastal waters at Lat. $51^{\circ} 21^{\prime} \mathrm{N}$, Long. $2^{\circ} 48^{\prime} \mathrm{E}$, during spring 1984 . Water samples were collected at sunrise at a depth of $3 \mathrm{~m}$ with 51 Niskin bottles. One 1 was immediately filtered on a GF/F Whatman filter for chlorophyll a determination and the filtrates were frozen for subsequent analysis. A further $100 \mathrm{ml}$ of seawater was fixed with Lugol's solution for phytoplankton determination.

Integrated measurements of total incident solar radiation were collected every $30 \mathrm{~min}$ by the 'Institut Royal Météorologique de Belgique' $10 \mathrm{~km}$ from the sampled station.

Chemical analysis. Chlorophyll a wds measured by the spectrophotometric method of Lorenzen (1967). Nitrate and nitrite were determined according to the procedure described by Armstrong et al. (1967). Ammonium was measured by the phenol hypochlorite method of Slawyk \& McIsaac (1972). The method for silica determination was adapted from the procedure described in Technicon Industrial Methods.
Phytoplanktonic activities measurement. Photosynthesis. Daily integrated carbon photo-assimilation by phytoplankton was calculated by means of the Platt et al. (1980) model from the experimental characterization of the photosynthesis-light relation for each sampled phytoplankton community.

The light-dependence of photosynthetic processes was experimentally determined by short-term ${ }^{14} \mathrm{C}$ bicarbonate incubations of natural colonies run around noon, under simulated in situ conditions on deck for different fractions $(0,6,10,18,32,44,56,76,100 \%)$ of the incident light intensity. Four incubation times $(0.5$, $1,2,4 \mathrm{~h}$ ) were used to test the importance of catabolic losses as a function of incubation time together with the adaptability of the colonies to maximal light intensities.

After incubation phytoplankton cells were separated from mucous substances and excreted products by means of $\mathrm{GF} / \mathrm{F}$ Whatman filters. Filtrates were acidified to $\mathrm{pH} 2.5$ and bubbled for $30 \mathrm{~min}$ in order to remove inorganic ${ }^{14} \mathrm{C}$.

Ultrafiltrations with 500 dalton membranes were used to separate exopolymeric mucilaginous substances from organic compounds released in the external medium by the colonies.

Cellular growth, catabolism and excretion of organic molecules. Daily integrated cellular growth was calculated by means of the mathematical model of protein synthesis by Phaeocystis pouchetii cells as previously described in Lancelot et al. (1986). Physiological parameters which express the control of protein synthesis were determined from data of long-term kinetics of ${ }^{14} \mathrm{C}$ incorporation into specific classes of intra- and extracellular products, run under simulated in situ at maximum light intensity from noon to sunrise. As previously described (Lancelot et al. 1986), such kinetics allow estimating the absolute rate of light and dark protein synthesis. Moreover, these time-course studies clearly showed catabolic losses of intracellular reserve products or exopolymeric substances, the relative rate of which is calculated by means of the mathematical model developed in Lancelot \& Mathot (1985a).

Experiments and biochemical procedures used for specific isolation of the different classes of metabolite are described in Lancelot \& Mathot (1985a) and Lancelot et al. (1986).

Heterotrophic utilization of phytoplankton-excreted products. Successive filtrations on filters of different nominal porosity $(2 \mu \mathrm{m}, 0.2 \mu \mathrm{m})$ were performed in parallel with time-course studies of phytoplankton metabolism, in order to estimate the uptake by bacteria of phytoplankton-excreted products. Experimental procedure is that described by Wolter (1982). Antibiotic controls were simultaneously incubated in parallel. 


\section{RESULTS}

\section{Temporal changes of environmental factors and phytoplankton biomass during spring bloom}

Fig. 1, 2 \& 3 show changes in seawater temperature, major nutrients and phytoplankton biomass, as measured in Belgian coastal waters during the course of the spring bloom 1984. Dominant phytoplanktonic species are also indicated. Seawater temperature was $7^{\circ} \mathrm{C}$ at the beginning of the spring bloom and increased by $3 \mathrm{C}^{\circ}$ during its course (Fig. 1). The spring bloom was

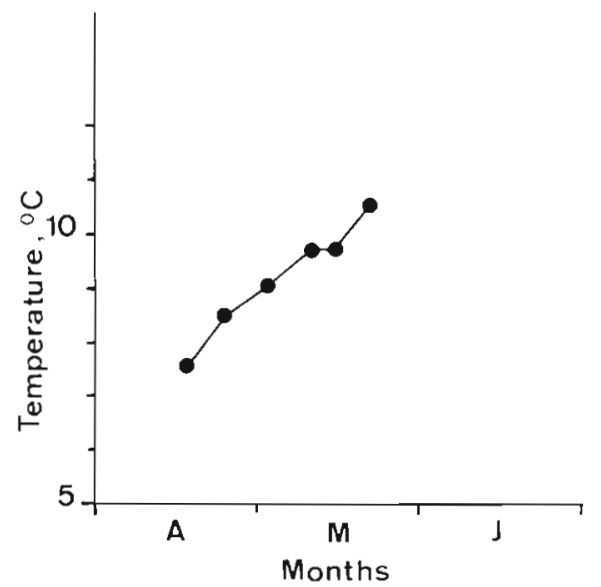

Fig. 1. Seawater temperature in Belgian coastal waters during spring 1984

clearly characterized by 2 peaks of phytoplankton biomass corresponding to the blooming of 2 distinct populations (Fig. 3). The first one, composed for the most part of the colonial diatom Chaetoceros socialis, culminated around $9 \mu \mathrm{g} \mathrm{Chl} \mathrm{a} \mathrm{l^{-1 }}$ in early April when the temperature was lower than $8^{\circ} \mathrm{C}$. The second one, more important, culminated 1 mo later, when seawater temperature had gained $2 \mathrm{C}^{\circ}$. Biomass was very high, around $20 \mu \mathrm{g} \mathrm{Chl} \mathrm{a}^{-1}$ and was $95 \%$ attributable to the bloom of Phaeocystis pouchetii colonies, the remainder being composed of diatoms. After the decline of $P$. pouchetii the phytoplanktonic community was composed of a few small flagellates.

The decline of Chaetoceros socialis corresponded to the depletion of ambient silicon, concentrations of which (Fig. 2b), although high in winter (about $20 \mu$ mole $1^{-1}$ ), are lower than the Michaelis constant reported for silicon uptake by Chaetoceros $\mathrm{sp}$. (0.5 to $2.2 \mu$ mole $1^{-1}$ ) (see review by Paasche 1980). Fig. $2 b$ shows, in addition, that silicon concentrations were kept at a very low level during the whole spring bloom. Phaeocystis pouchetii colonies, on the other hand, do not require silicic acid and their growth should be controlled either by inorganic nitrogen or phosphate. Unfortunately, no data on phosphate concentration in our area during spring 1984 are available. However, measurements performed in the Belgian coastal zone in 1977 to 1979 (Mommaerts pers. comm.) never
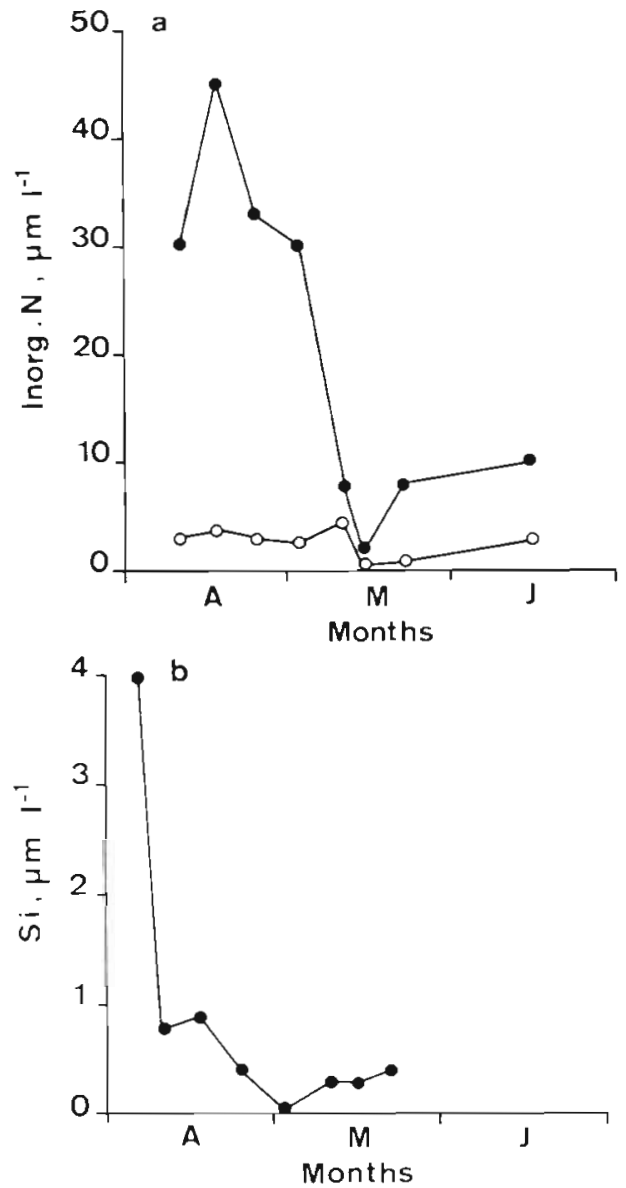

Fig. 2. Inorganic nutrients in Belgian coastal waters during spring 1984. (a) Nitrate (•); ammonium (O). (b) Silicon

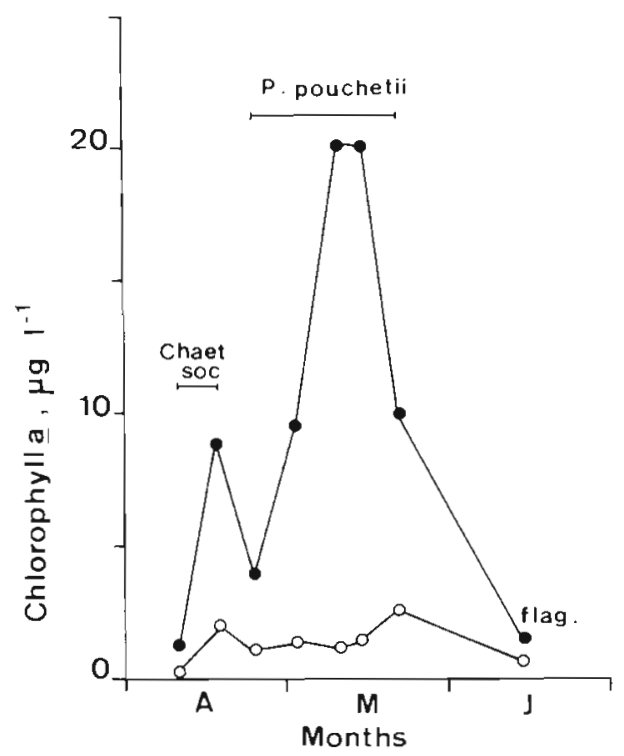

Fig. 3. Chlorophyll a $(\bullet)$ and degraded products $(0)$ in Belgian coastal waters during spring 1984 
showed very sharp seasonal variations in phosphate concentrations which were always higher than $0.5 \mu$ mole $1^{-1}$, even during the spring bloom. In contrast, nitrate and ammonium concentrations decreased very rapidly during the outburst of the $P$. pouchetii bloom and reached values significantly lower than the Michaelis constant for nitrogen assimilation by $P$. pouchetii (i.e. $4 \mu \mathrm{mole}^{-1}$; Lancelot et al. 1986). After the decline of $P$. pouchetii colonies, ambient inorganic nitrogen concentrations reached non-limiting levels again.

\section{Phytoplanktonic activities}

Photosynthetic parameters

Fig. 4 \& 5 give 2 typical examples of the short-term time dependence of the photosynthesis-light relation of a phytoplanktonic community dominated respectively by Chaetoceros socialis and Phaeocystis pouchetii colonies.

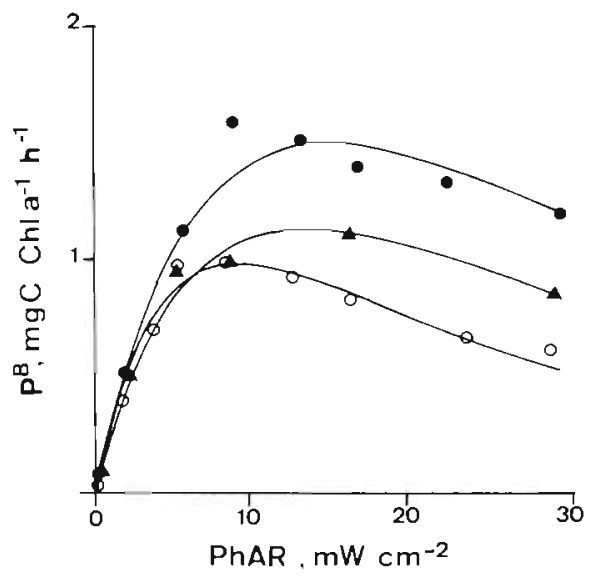

Fig. 4. Chaetoceros socialis-dominated phytoplankton population. Relation between specific photosynthetic rate $\left(\mathrm{P}^{\mathrm{B}}\right)$ and photosynthetically active radiation (PhAR) for different incubation times: $(\bullet) 0.58 \mathrm{~h} ;(\Delta) 1.16 \mathrm{~h} ;$ (0) $4.16 \mathrm{~h}$

Changes with incubation time of the photosynthesislight relation by Chaetoceros socialis (Fig. 4) are typical of that generally encountered for diatoms (Marra 1980), i.e. low but constant photosynthesis rates over time at low light intensities and strong photoinhibition at high light intensities, increasing over time. In contrast, the photosynthesis-light relation of Phaeocystis pouchetii colonies does not show significant changes with increasing incubation times (Fig. 5a, b). However, the major trend of photosynthetic properties of $P$. pouchetii colonies lies in the quite significant difference existing between the control by light of cellular carbon photo-assimilation rate (Fig. 5a) and mucus

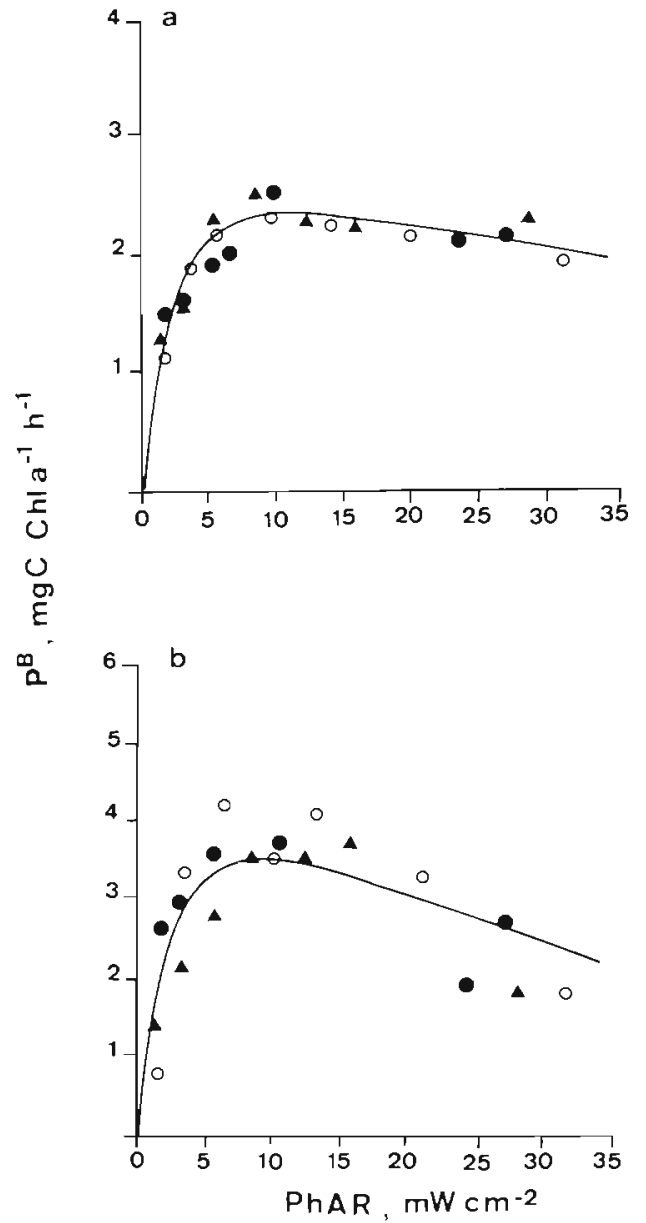

Fig. 5. Phaeocystis pouchetii colonies-dominated phytoplanktonic population. Relation between specific photosynthetic rate $\left(\mathrm{P}^{8}\right)$ and photosynthetically active radiation (PhAR) for different incubation times: (๑) $0.8 \mathrm{~h}$; (4) $1.3 \mathrm{~h}$; (O) $4.3 \mathrm{~h}$. (a) Cellular photosynthesis; (b) mucus secretion

secretion (Fig. 5b). The latter photosynthetic process, although enhanced at intermediate light intensities, was strongly photoinhibited by high light intensities. Cellular photosynthesis, on the other hand, reached maximal rates at low light intensities and was not photoinhibited. Considering that $P$. pouchetii colonies act as biological entities and that mucus constitutes an energetic substrate for cell growth (Lancelot \& Mathot 1985b), this agrees well with previous work (see review by Morris 1980), which shows that photosynthesis of storage products is enhanced at high light intensities. In addition, the severe photoinhibition of mucus secretion occurring at high light intensities would suggest that high light specifically represses one of the steps leading to the synthesis of mucus.

The mathematical formulation by Platt et al. (1980) of the light saturation curve was found to provide the best fit of experimental data relative to spring phytoplankton in Belgian coastal waters. Values of charac- 

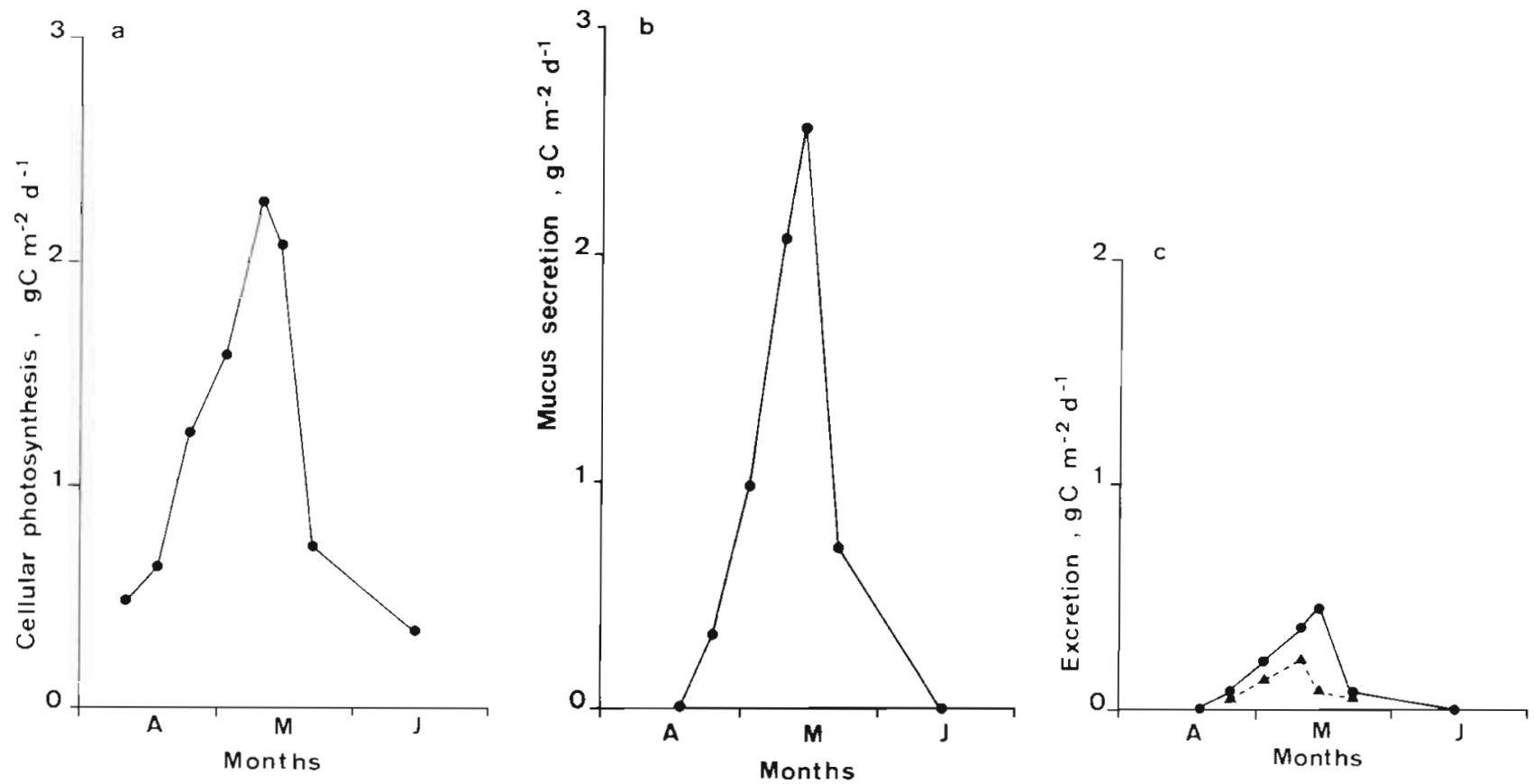

Fig. 6. Phaeocystis pouchetii colonies. Daylight photosynthesis rates during spring 1984. (a) Cells; (b) mucus; (c) excretion ( $\bullet$ ) and direct utilization of excreted products by bacteria ( $\mathbf{\Lambda})$

At the most developed stage of Phaeocystis pouchetii, where ambient inorganic nitrogen reached its lowest level (Fig. 2), daily rates of mucus secretion (Fig. 6b) were higher than carbon assimilation rates by colonial cells (Fig. 6a), in close agreement with previ-
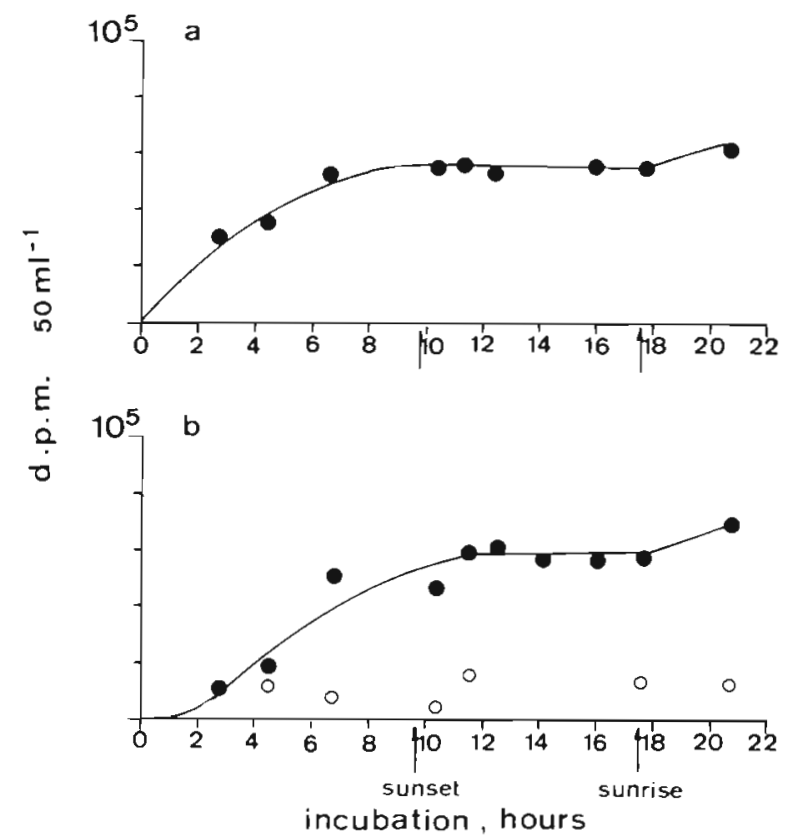

Fig. 7. Phaeocystis pouchetii. (a) Long-term kinetics of ${ }^{14} \mathrm{C}$ bicarbonate incorporation into excreted product by colonies. (b) Long-term kinetics of uptake by bacteria of ${ }^{14} \mathrm{C}$ excreted products by $P$. pouchetii colonies. (O) Antibiotic control ous results (Lancelot 1983). Excretion rate (Fig. 6c), on the other hand, was never an important process amounting to between 0 and less than $10 \%$ of the total photosynthetic rate, in accordance with the recent review by Lancelot \& Billen (1986).

Uptake by bacteria of phytoplankton-excreted products was deduced from data on successive filtrations, performed on planktonic communities incubated at maximal light intensity during a natural light:dark cycle, assuming that excreted products were in isotopic equilibrium with external ${ }^{14} \mathrm{C}$-bicarbonate. Fig. 7 , which illustrates such experiments, shows clearly a close coupling between excretion of organic molecules by phytoplankton and their use by bacteria. Daily uptake by bacteria of phytoplankton-excreted products in the water column was then calculated from daily excretion rates, assuming that the proportion of excreted products taken up by bacteria observed during incubation at maximal light intensity remains the same at the other light intensities. Results of these calculations (Fig. 6c) show that bacteria utilize from 16 to $90 \%$ of phytoplankton-excreted products.

\section{Growth and catabolism}

Daily Phaeocystis pouchetii cell growth in the water column was calculated by means of the mathematical model of protein synthesis previously described by Lancelot et al. (1986) from data of biomass, ambient 
inorganic nitrogen, hourly incident photosynthetically active radiation (PhAR) and vertical light attenuation coefficient. Physiological parameters, which express the control of protein synthesis, were those reported in Lancelot et al. (1986). Fig. 8 gives the seasonal changes

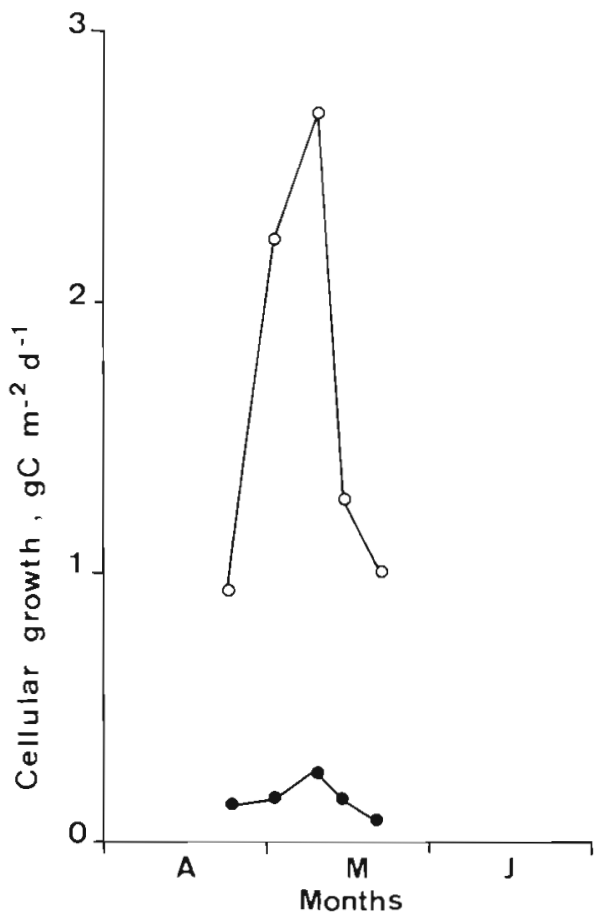

Fig. 8. Phaeocystis pouchetii. Daily (i.e. 24 h) (O) and dark (•) cellular growth during spring bloom 1984

of daily and dark $P$. pouchetii cell growth during the spring bloom 1984. It shows that dark growth, although sometimes as important as light growth in surface waters (Lancelot et al. 1986), is never an important process when integrated over the water column. It accounts for 7 to $15 \%$ of total daily growth in the water column. Indeed, the high turbidity which characterizes Belgian coastal waters reduces the vertical light penetration, diminishing the size of photosynthetized energetic substrates, catabolic products of which are required for the dark growth of the cells.

As discussed previously (Lancelot et al, 1986), daily (i.e. $24 \mathrm{~h}$ ) cellular growth rate was generally lower than cellular photosynthesis except at high levels of ambient inorganic nitrogen, where significantly higher daily growth rates were calculated. This is a special property of colonial algae, the energetic substrates of which are mainly exopolymeric.

Turnover rates of Phaeocystis pouchetii cells could be calculated from data on growth rate (Fig. 8) and chlorophyll a (Fig. 3), assuming a C/Chl a ratio of 30 for $P$. pouchetii cells (Lancelot-Van Beveren 1980). Calculated values, significantly correlated to ambient inor- ganic nitrogen $(r=0.98)$ range between 0.12 and $0.38 \mathrm{~d}^{-1}$ in close agreement with those reported by Eilertsen \& Taasen (1983) for Norwegian coastal waters.

Relative rates of dark catabolism of exopolymeric substances were calculated from ${ }^{14} \mathrm{C}$ kinetics, during a $24 \mathrm{~h}$ cycle (see Lancelot et al. 1986), by means of the model developed in Lancelot \& Mathot (1985a). In this model, catabolism of storage products is assumed to obey first-order kinetics. Results of these calculations are reported in Table 2 . This table shows important

Table 2. Phaeocystis pouchetii. Relative rate of dark catabolism of mucus as calculated from the kinetics described in Lancelot et al. (1986) by means of the model developed in Lancelot \& Mathot (1985a)

\begin{tabular}{|rc|}
\hline Samples & Dark catabolism $\left(\mathrm{h}^{-1}\right)$ \\
\hline 24 Apr 84 & 0.2 \\
2 Apr 84 & 0.1 \\
1 Apr 84 & 0.02 \\
14 Apr 84 & 0.2 \\
21 Apr 84 & 0.1 \\
\hline
\end{tabular}

catabolism relative rates, similar to that calculated for intracellular reserve polysaccharides of diatoms (Lancelot \& Mathot 1985a). Unfortunately, absolute rates of dark catabolism of Phaeocystis pouchetii mucilaginous substances and hence net secretion of miucus matrix cannot be estimated at the present time, because the specific radioactivity of exopolymeric storage products is unknown, due to the lack of accurate chemical methods for isolation and determination of these compounds.

\section{DISCUSSION AND CONCLUSIONS}

Phaeocystis pouchetii is a very common spring alga of northern coastal and estuarine waters where spectacularly high biomasses of colonial forms are reported almost every year (Table 3 ). As shown by Table 4 , which summarizes available literature data on environmental factors related to the presence of $P$. pouchetii colonies, this Haptophycea, which appears after diatoms, seems to be able to grow under very varied environmental conditions. However, paradoxically, in spite of the ubiquity of this species, little is known on its growth and the factors controlling it.

This paper, which reports measurements of photosynthesis and growth rates during the course of a Phaeocystis pouchetii bloom, indicates clearly the lack of parallelism between photosynthesis rate and growth rate. Photosynthesis rates by $P$. pouchetii cells and 
Table 3. Phaeocystis pouchetii. Bloom period and biomass maxima in Northern Atlantic waters

\begin{tabular}{|c|c|c|c|c|c|}
\hline Biotopes & $\begin{array}{l}\text { Spring bloom } \\
\text { period }(\mathrm{mo})\end{array}$ & $\begin{array}{c}\text { Chla } \\
\left(\mu \mathrm{g} \mathrm{l}^{-1}\right)\end{array}$ & $\begin{array}{c}\text { Cells } \\
\left(\text { no. } ~^{-1}\right)\end{array}$ & $\begin{array}{l}\text { Colonies } \\
\left(\text { no. } 1^{-1}\right)\end{array}$ & Source \\
\hline $\begin{array}{l}\text { Balsfjorden } \\
\text { (Northern Norway) }\end{array}$ & $1.5^{\mathrm{a}}$ & ND & $10^{6}$ & ND & Eilertsen et al. (1981a) \\
\hline Eastern Irish Sea & 1.5 & ND & $10^{6}$ & 5000 & Jones \& Haq (1963), Cadée (1982) \\
\hline $\begin{array}{l}\text { Wadden Sea } \\
\text { (Westernost Inlet) }\end{array}$ & $\mathrm{b}$ & $40-120$ & $10^{6}$ & ND & Cadée \& Hegeman (1986) \\
\hline $\begin{array}{l}\text { Wadden Sea of Sylt } \\
\text { (German Bight) }\end{array}$ & & & & & Weisse et al. (1986) \\
\hline $1975-1976$ & 1.5 & & $10^{7}$ & & \\
\hline 1981 & 1.5 & 25 & & 30000 & \\
\hline Oosterschelde & 1 & 6 & $10^{7}$ & ND & Laanbroek et al. (1985) \\
\hline Ems-Dollart Estuary & 1 & $10-30$ & $>10^{6}$ & ND & Colijn (1983) \\
\hline $\begin{array}{l}\text { Dutch coastal waters } \\
1975 \\
1984\end{array}$ & $\begin{array}{l}1.5 \\
1\end{array}$ & $\begin{array}{l}10 \\
11\end{array}$ & $\begin{array}{l}\text { ND } \\
10^{6}\end{array}$ & $\begin{array}{l}\text { ND } \\
\text { ND }\end{array}$ & $\begin{array}{l}\text { Gieskes \& Kraay (1975) } \\
\text { Veldhuis et al. } 1986\end{array}$ \\
\hline Belgian coastal waters & $1-1.5$ & 20 & ND & ND & This paper \\
\hline
\end{tabular}

Table 4. Phaeocystis pouchetii bloom and environmental parameters in Northern Atlantic waters

\begin{tabular}{|c|c|c|c|c|c|c|c|}
\hline Biotopes & $\begin{array}{l}\text { Salinity } \\
(\%)\end{array}$ & $\begin{array}{l}\text { Temp } \\
\left({ }^{\circ} \mathrm{C}\right)\end{array}$ & $\begin{array}{c}\eta^{a} \\
\left(m^{-1}\right)\end{array}$ & $\begin{array}{l}\text { Inorg. } N \\
\left(\mu \mathrm{g}-\text { at } l^{-1}\right)\end{array}$ & $\begin{array}{l}\text { Inorg. } P \\
\left(\mu \mathrm{g} \text {-at } \mathrm{l}^{-1}\right)\end{array}$ & $\begin{array}{c}\text { Previous dominant } \\
\text { diatom }\end{array}$ & Source \\
\hline $\begin{array}{l}\text { Balsfjorden } \\
\text { (Northern Norway) }\end{array}$ & $32.8-34$ & $3-10$ & 0.13 & $6-1$ & $2-0.6$ & $\begin{array}{l}\text { Chaetoceros socialis } \\
\text { Nitzschia grunowi }\end{array}$ & $\begin{array}{l}\text { Eilertsen et al. } \\
(1981 \mathrm{a}, \mathrm{b}) \\
\text { Eilertsen \& Taasen } \\
(1983)\end{array}$ \\
\hline Eastern Irish Sea & & $8-11$ & & & $16-1$ & $\begin{array}{l}\text { Chaetoceros sp. } \\
\text { Skeletonema costatum }\end{array}$ & $\begin{array}{l}\text { Jones \& Haq (1963) } \\
\text { Van Bennekom et al. } \\
(1975)\end{array}$ \\
\hline $\begin{array}{l}\text { Wadden Sea } \\
\text { (Westernost Inlet) }\end{array}$ & 30 & $3-12$ & 1 & $30-4$ & & Chaetoceros socialis & $\begin{array}{l}\text { Cadée \& Hegeman } \\
\text { (1986) }\end{array}$ \\
\hline $\begin{array}{l}\text { Wadden sea of Sylt } \\
\text { (German Bight) }\end{array}$ & & $8-12$ & & 2-und. & $0.4-$ und & & Weisse et al. 1986 \\
\hline Oosterschelde & 27 & & & $40-60$ & $1.5-0.6$ & $\begin{array}{l}\text { Skeletonema costatum } \\
\text { Thalassiosira sp. }\end{array}$ & $\begin{array}{l}\text { Laanbroek et al. } \\
\text { (1985) }\end{array}$ \\
\hline Ems-Dollart Estuary & $20-29$ & 18 & 1.6 & 30 & & $\begin{array}{l}\text { Skeletonema costatum } \\
\text { Asterionella glacialis }\end{array}$ & Colijn (1983) \\
\hline $\begin{array}{l}\text { Dutch coastal waters } \\
1975\end{array}$ & $30-33$ & 8 & & & & $\begin{array}{l}\text { Biddulphia } \\
\text { Chaetoceros sp. }\end{array}$ & $\begin{array}{l}\text { Gieskes \& Kraay } \\
(1975)\end{array}$ \\
\hline 1984 & & $7.5-11.5$ & & & $1.3-0.6$ & $\begin{array}{l}\text { Nitzschia grunowi } \\
\text { Asterionella glacialis } \\
\text { Skeleronema costatum }\end{array}$ & Veldhuis et al. (1986) \\
\hline $\begin{array}{l}\text { Belgian coastal waters } \\
\quad 1984\end{array}$ & 30 & $8.5-10.5$ & 0.5 & $45-2.6$ & $0.5-5$ & Chaetoceros socialis & This paper \\
\hline
\end{tabular}


colonial matrix secretion were found to be independent of temperature and ambient inorganic nutrient, at least in the range of variation fixed by the environment. Also the laws which govern photosynthetic processes for $P$. pouchetii cells and for their mucus envelope were found to be independent. Maximal specific photosynthetic rates were respectively 0.09 and $0.16 \mathrm{~h}^{-1}$ for cells and mucus. Similarly, lightsaturation parameters of mucus were about twice as high as those of cells. Growth rate of $P$. pouchetii cells, on the other hand, was found to be directly correlated to the level of ambient inorganic nitrogen. Turnover rates of $P$. pouchetii cells were shown to vary between $0.38 \mathrm{~d}^{-1}$ with high external inorganic nitrogen and $0.12 \mathrm{~d}^{-1}$ when nitrogen was at its lowest level.

With the knowledge of photosynthesis and growth by Phaeocystis pouchetii colonies and their control by environmental variables, it was possible to establish a budget of their metabolism for the spring bloom 1984. This was deduced by integration of Fig. $6 \& 8$ for the whole period of the $P$. pouchetii bloom, i.e. from 24 April to 21 May. Results of these calculations are reported in Table 5. This table shows that $94 \mathrm{~g} \mathrm{C} \mathrm{m}^{-2}$

Table 5. Phaeocystis pouchetii. Metabolic activities by colonies in Belgian coastal waters during the spring bloom 1984

\begin{tabular}{|c|c|c|}
\hline Process & Structure & $\begin{array}{c}\text { Activity } \\
\left(\mathrm{g} \mathrm{C} \mathrm{m}^{-2} \mathrm{mo}^{-1}\right)\end{array}$ \\
\hline Photosynthesis & $\begin{array}{l}\text { Colonies } \\
\text { Cells } \\
\text { Mucus } \\
\text { Excretion }\end{array}$ & $\begin{array}{l}94 \\
47.5 \\
39 \\
7.5\end{array}$ \\
\hline Respiration & $\begin{array}{l}\text { Cells } \\
\text { Mucus }\end{array}$ & $\begin{array}{l}2.5 \\
?\end{array}$ \\
\hline Growth & $\begin{array}{l}\text { Colonies } \\
\text { Cells } \\
\text { Mucus }\end{array}$ & $\begin{array}{r}\leqslant 84 \\
50.6 \\
\leqslant 33.4\end{array}$ \\
\hline Mortality & Cells & 47.3 \\
\hline
\end{tabular}

were photo-assimilated by $P$. pouchetii colonies during the spring bloom. Of this, $41.5 \%$ was secreted as mucilaginous substances composing the colonial matrix, and $8 \%$ was excreted directly as small molecules from the colonies and was directly usable by bacteria. Integration of Fig. $6 \mathrm{c}$ gives an estimate of up to $40 \%$ bacterial utilization of these products. Growth rate of $P$. pouchetii cells, on the other hand, was estimated to $50.6 \mathrm{~g} \mathrm{C} \mathrm{m}^{-2}$. Of this, $89 \%$ i.e. $45 \mathrm{~g} \mathrm{C} \mathrm{m}^{-2}$ proceeded during the photoperiod, the remainder occurring during the dark at the expense of mucilaginous substances as previously described (Lancelot \& Mathot 1985b). Direct comparison between photosynthetic rates and light and dark growth rates allows estimation of cellu- lar and mucous catabolic losses. Indeed, cellular respiration during the light period could be deduced from the difference between cellular photosynthesis and cellular growth during the photoperiod. The result of this calculation shows that cellular respiration accounts for $5 \%$ of cellular photosynthesis. In a similar way, a minimum value for catabolic losses of mucus can be deduced from night cellular growth which results from dark mobilization of mucus itself. A maximum estimate of net mucus secretion is therefore given by the difference between mucus photosynthesis rate and night cellular growth, i.e. $33.4 \mathrm{~g} \mathrm{C} \mathrm{m}^{-2}$. This latter value combined with that of colonial cell growth rate gives an estimate for $P$. pouchetii colonies growth in Belgian coastal waters of $84 \mathrm{~g} \mathrm{C} \mathrm{m}^{-2} \mathrm{mo}^{-1}$.

Finally, mortality rate of Phaeocystis pouchetii cells resulting mostly from physiological death or sedimentation in the absence of significant zooplankton grazing at this period of the year (Joiris et al. 1982, Fransz \& Gieskes 1984) could be estimated by comparing daily growth rate (Fig. 7 ) and the rate of change of phytoplankton biomass (Fig. 3). Results of these calculations show that the relative rate of mortality ranges from 0.15 to $0.29 \mathrm{~d}^{-1}$, in good agreement with the range of turnover rates. From these, mortality of $P$, pouchetii cells was estimated at $47 \mathrm{~g} \mathrm{C} \mathrm{m}^{-2} \mathrm{mo}^{-1}$.

Such an estimate of the budget of metabolic activities by Phaeocystis pouchetii colonies constitutes an essential step for the understanding of organic matter cycling at the first trophic levels of the food web of a coastal marine system entirely dominatcd by $P$. pouchctii during its spring bloom. Billen \& Fontigny (Part II of this series; p. 249-257) discuss the utilization of organic matter by planktonic bacteria during the same bloom of $P$. pouchetii.

Acknowledgements. This work was financially supported by the E.E.C., contract ENV. 862-B and by the Ministry of Science Policy. We thank E. Stainier for nutrient determinations.

\section{LITERATURE CITED}

Armstrong, F. A., Stems, A. J., Strickland, J. D. H. (1967). The measurement of upwelling and subsequent biological processes by means of the Technicon autoanalyses. Deep Sea Res. 14: 381-387

Cadée, G. C. (1982). Tidal and seasonal variation in particulate and dissolved organic carbon in the western Dutch Wadden Sea and Marsdiep tidal inlet. Neth. J. Sea Res. 15: $228-249$

Cadée, G. C., Hegeman, J. (1986). Seasonal and annual variation of Phaeocystis pouchetii (Haptophyceae) in the Westernost inlet of the Wadden Sea during the 1973 and 1985 period. Neth. J. Sea Res.: 20 (1): 29-36

Colijn, F. (1983). Primary production in the Ems-Dollart estuary. Ph.D. thesis, Rijksuniversieteit te Groningen. Van Denderen BV, Groningen 
Cook, J. R. (1966). Photosynthetic activity during the division cycle in synchronized Euglena gracilis. Pl. Physiol., Wash. 41: 821-825

Cuhel, R. L., Ortner, P. B., Lean, D. R. S. (1984). Night synthesis of protein by algae. Limnol. Oceanogr. 29: $731-744$

Eilertsen, H. C., Taasen, J. P. (1983). Investigations on the plankton community of Balsfjorden, northern Norway. The phytoplankton 1976-1978. Environmental factors, dynamics of growth and primary production. Sarsia 68 : $1-15$

Eilertsen, H. C., Schei, B., Taasen, J. P. (1981a). Investigations on the plankton community of Balsfjorden, northern Norway. The phytoplankton 1976-1978. Abundance, species composition and succession. Sarsia 66: 129-141

Eilertsen, H. C., Falk-Petersen, S., Hopkins, C. C. E., Tande, K. (1981b). Ecological investigations on the plankton community of Balsfjorden, northern Norway. Program for the project, study area, topography and physical environment. Sarsia 66: 25-34

Foy, R. H., Smith, R. V. (1980). The role of carbohydrate accumulation in the growth of planktonic Oscillatoria species. Br. phycol. J. 15: 139-150

Fransz, H. G., Gieskes, W. W. C. (1984). The unbalance of phytoplankton and copepods in the North Sea. Rapp. P.-v. Réun. Cons. int. Explor. Mer 183: 218-225

Gieskes, W. W. C., Kraay, G. W. (1975). The phytoplankton spring bloom in Dutch coastal waters of the North Sea. Neth. J. Sea Res. 9 (a): 166-196

Joiris, C., Billen, G., Lancelot, C., Daro, M. H., Mommaerts, J. P., Bertels, A., Bossicart, M., Nys, J. (1982). A budget of carbon cycling in the Belgian coastal zone: relative roles of zooplankton, bacterioplankton and benthos in the utilization of primary production. Neth. J. Sea Res. 16: $260-275$

Jones, P. G. W., Haq, S. M. (1963). The distribution of Phaeocystis in the Eastern Irish Sea. J. Cons. perm. int Explor. Mer 28: 8-19

Laanbroek, H. J., Verplanke, J. C., Visscher, P. R. M. de Vuyst, R. de (1985). Distribution of phyto- and bacterioplankton growth and biomass parameters, dissolved inorganic nutrients and free amino acids during a spring bloom in the Oosterschelde basin, The Netherlands. Mar. Ecol. Prog. Ser. 25: 1-11

Lancelot-Van Beveren, C. (1980). A statistical method to estimate the biochemical composition of phytoplankton in the Southern Bight of the North Sea. Estuar. coast. mar. Sci. 10: $467-478$

Lancelot, C. (1983). Metabolic changes in Phaeocystis pouchetii (Hariot) Lagerheim during the spring bloom in Belgian coastal waters. Estuar, coast. Shelf Sci. 18 593-600
Lancelot, C., Mathot, S. (1985a). Biochemical fractionation of primary production by phytoplankton in Belgian coastal waters during short- and long-term incubations with ${ }^{14} \mathrm{C}$ bicarbonate. I. Mixed diatom population. Mar. Biol. 86: $219-226$

Lancelot, C., Mathot, S. (1985b). Biochemical fractionation of primary production by phytoplankton in Belgian coastal waters during short- and long-term incubations with ${ }^{14} \mathrm{C}$ bicarbonate. II. Phaeocystis pouchetii colonial population. Mar. Biol. 86: 227-232

Lancelot, C., Billen, G. (1986). Carbon-nitrogen relationships in nutrient metabolism of coastal marine ecosystems. Adv. aquat. Microbiol. 3: 263-321

Lancelot, C., Mathot, S., Owens, N. J. P. (1986). Modelling protein synthesis, a step to an accurate estimate of net primary production: Phaeocystis pouchetii colonies in Belgian coastal waters. Mar. Ecol. Prog. Ser. 32: 193-202

Lorenzen, C. (1967). Determination of chlorophyll and phaeopigments: spectrometric equations. Limnol. Oceanogr. 12: 343-347

Marra, J. (1980). Vertical mixing and primary production. In: Falkowski, P. G. (ed.) Primary production in the sea. Plenum Press, New York, p. 121-137

Morris, I. (1980). Paths of carbon assimilation in marine phytoplankton. In: Falkowski, P. G. (ed.) Primary productivity in the sea. Plenum Press, New York, p. 139-159

Paasche, E. (1980). Silicon. In: Morris, I. (ed.) The physiological ecology of phytoplankton, Vol. 7, Studies in Ecology. Blackwell Scientific Publications, Oxford, p. 259-284

Platt, T., Gallegos, C. L., Harrison, W. G. (1980). Photoinhibition of photosynthesis in natural assemblages of marine phytoplankton. J. mar. Res. 38 (4): 687-701

Slawyk, G., McIsaac, J. J. (1972). Comparison of two automated ammonium methods in a region of coastal upwelling. Deep Sea Res. 19: 1-4

Van Bennekom, A. J., Gieskes, W. W. C., Tijssen, S. B. (1975). Eutrophication of Dutch coastal waters. Proc. R. Soc. Lond. (B) 189: 359-375

Veldhuis, M. J. W., Admiraal, W., Colijn, F. (1986). Chemical and physiological changes of phytoplankton during the spring bloom, dominated by Phaeocystis pouchetii (Haptophycea): observations in Dutch coastal waters of the North Sea. Neth. J. Sea Res. 20 (1): 49-60

Weisse, T., Grim, N., Hickel, W., Martens, P. (1986). On the causes and dynamics of Phaeocystis pouchetii blooms in the wadden sea of Sylt (German Bight, North Sea). Estuar. coast. Shelf Sci. 23: 171-182

Wolter, K. (1982). Bacterial incorporation of organic substances released by natural phytoplankton populations. Mar. Ecol. Prog. Ser. 7: 287-295 